University of Nebraska - Lincoln

DigitalCommons@University of Nebraska - Lincoln

$6-2003$

\title{
Observations on the Life History and Descriptions of Coccidia (Apicomplexa) from the Western Chorus Frog, Pseudacris triseriata triseriata, from Eastern Nebraska
}

\author{
Matthew G. Bolek \\ Oklahoma State University, bolek@okstate.edu \\ John J. Janovy Jr. \\ University of Nebraska - Lincoln, jjanovy1@unl.edu \\ Armando R. Irizarry-Rovira \\ Lilly Research Laboratories
}

Follow this and additional works at: https://digitalcommons.unl.edu/bioscijanovy

Part of the Parasitology Commons

Bolek, Matthew G.; Janovy, John J. Jr.; and Irizarry-Rovira, Armando R., "Observations on the Life History and Descriptions of Coccidia (Apicomplexa) from the Western Chorus Frog, Pseudacris triseriata triseriata, from Eastern Nebraska" (2003). John Janovy Publications. 51.

https://digitalcommons.unl.edu/bioscijanovy/51

This Article is brought to you for free and open access by the Papers in the Biological Sciences at DigitalCommons@University of Nebraska - Lincoln. It has been accepted for inclusion in John Janovy Publications by an authorized administrator of DigitalCommons@University of Nebraska - Lincoln. 


\title{
OBSERVATIONS ON THE LIFE HISTORY AND DESCRIPTIONS OF COCCIDIA (APICOMPLEXA) FROM THE WESTERN CHORUS FROG, PSEUDACRIS TRISERIATA TRISERIATA, FROM EASTERN NEBRASKA
}

\author{
Matthew G. Bolek, John Janovy, Jr., and Armando R. Irizarry-Rovira* \\ School of Biological Sciences, University of Nebraska-Lincoln, Lincoln, Nebraska 68588. e-mail: mbolek@unlserve.unl.edu
}

\begin{abstract}
Two hundred and twenty-four anurans of 6 species (47 adults and 16 tadpoles of Rana blairi, 35 R. catesbeiana, 31 Hyla chrysoscelis, 30 adults and 46 tadpoles of Pseudacris triseriata triseriata, 11 Bufo woodhousii, and 8 Acris crepitans) from Pawnee Lake, Lancaster County, Nebraska, were surveyed for coccidian parasites during March 2001 to May 2002. Of these, 23 of $30(77 \%)$ adults and 4 of $46(9 \%)$ tadpoles of $P$. t. triseriata shed oocysts of Isospora cogginsi n. sp. Oocysts of $I$. cogginsi were ovoid, $19.3 \times 15.1(18-23 \times 11-20) \mu \mathrm{m}$, with a thin, smooth, colorless, single-layered wall, with no micropyle or oocyst residuum. Sporocysts were ovoid, $13.3 \times 9.9(11-15 \times 9-13) \mu \mathrm{m}$, with a thin, colorless, smooth wall, and Stieda body absent. Sporocyst residuum was present, $5.5 \times 5.3(4-7 \times 4-7) \mu \mathrm{m}$, consisting of numerous granules. Histological examination of frogs and tadpoles infected with the new species revealed endogenous stages including mature meronts, developing microgamonts, mature microgametes, mature macrogamonts, and young unsporulated oocysts located in the cytoplasm of the epithelial cells of the small intestine. Concurrently, 2 adult $P$. t. triseriata shed oocysts of Eimeria streckeri. Oocysts of E. streckeri were spherical, $15.7 \times 15.4(14-17 \times 14-19) \mu \mathrm{m}$, with a thin, smooth, single-layered, colorless wall with an oocyst residuum composed of numerous granules surrounding a large vacuolated area, with a previously undescribed globularlike body present within the vacuole, and no micropyle. Sporocysts were ovoid, $9.1 \times 6.1(7-10 \times 5-7) \mu \mathrm{m}$, with a thin, colorless, smooth wall with a Stieda body and sporocyst residuum. Our results are the first to document infection of adult and tadpole stages of frogs of the same species with the same species of coccidian, indicating that adult frogs may contaminate breeding ponds with oocysts during their breeding season and infect tadpoles directly by the ingestion of sporulated oocysts.
\end{abstract}

Coccidia of anurans include many species whose taxonomic affinities and host specificity can only be inferred. The difficulty of working with these frail coccidians probably contributes to the lack of new species descriptions and life-history studies (Upton and McAllister, 1988; Paperna and Lainson, 1995; Modry et al., 2001). Most studies of anuran coccidia date to the earlier part of the 20th century, and most focused on Holarctic host species (Laveran and Mesnil, 1902; Noller, 1920). Only recently have taxonomic studies been conducted on anuran coccidia from North America. Upton and McAllister (1988) examined adult, juvenile, and tadpole anurans of 12 species and reported 2 new species of Eimeria and 1 new species of Isospora from adult Pseudacris streckeri Wright and Wright, 1933 and 1 new species of Isospora from adult Gastrophryne olivacea Hallowell, 1856. Chen and Desser (1989) and McAllister et al. (1995) collectively described 3 new species of Eimeria from adult Rana catesbeiana Shaw, 1802, $R$. clamitans Latreille, 1820, R. septentrionalis Baird, 1854, and $R$. sylvatica LeConte, 1825, from Sasajewun, Algonquin Park, Ontario, Canada, and $R$. sylvatica, from Izard County, Arkansas, respectively.

Between March 2001 and June 2002, we conducted a survey of 6 species of anurans from Pawnee Lake, Lancaster County, Nebraska, for coccidian parasites. Recent studies by Bolek and Coggins (1998) and Goldberg et al. (2002) reviewed the parasites of the western chorus frog, $P$. triseriata triseriata, and did not report any coccidian parasites infecting these amphibians. However, at Pawnee Lake we found 2 species of coccidians that have not been previously reported from $P$. $t$. triseriata. Here, we describe these species, provide prevalence information and host specificity data on other anurans from this location, and suggest a mechanism by which $P$. $t$. triseriata becomes infected with the Isospora species.

Received 18 October 2002; revised 18 December 2002; accepted 20 December 2002.

* Department of Pathology, Lilly Research Laboratories, Drop Code GL44, Eli Lilly and Company, Greenfield, Indiana 46140.

\section{MATERIALS AND METHODS}

Adult anurans were collected at night by hand from Pawnee Lake, Lancaster County, Nebraska $\left(40^{\circ} 51.18^{\prime} \mathrm{N}, 96^{\circ} 53.11^{\prime} \mathrm{W}\right)$ during their breeding season from March 2001 to May 2002. Thirty P. t. triseriata tadpoles were collected using a dip-net during April 2002. Additionally, $16 P$. $t$. triseriata and $16 R$. blairi tadpoles were collected during May and June of 2002, maintained in the laboratory for a period of 2-6 wk in a single 37.8- $\mathrm{L}$ tank, and fed frozen mustard greens. Tadpoles were isolated in 4-ml vials containing tap water and examined for shedding oocysts during June 2002. All amphibians were identified according to keys of Collins (1993) and Vogt (1981), and all tadpoles were aged according to Gosner (1960). Adult frogs were brought to the laboratory, pithed, and necropsied within $72 \mathrm{hr}$ of collection. Fecal contents were examined microscopically at the time of necropsy. Tadpoles were brought to the laboratory and placed in individual 4-ml vials in tap water. All fecal material and tadpole intestinal contents were examined for the presence of coccidian oocysts within $24 \mathrm{hr}$ of collection.

All positive samples containing oocysts were placed in $2.5 \%$ potassium dichromate, kept at room temperature in petri dishes, and examined during a period of $2 \mathrm{wk}$. Measurements of 30 oocysts of each species were made with the aid of a calibrated ocular micrometer and reported in micrometers with the mean followed by the range in parentheses. A Jeneval photomicroscope equipped with Nomarski interference contrast optics was used to photograph specimens, and line drawings were made from photomicrographs and direct observations.

The small intestines of all infected frogs and 3 infected tadpoles were fixed in Bouin's fixative, processed routinely and embedded in paraffin, sectioned at 5-12 $\mu \mathrm{m}$, affixed to slides, stained with hematoxylin and eosin, mounted in Canada balsam or Permount, and examined microscopically for endogenous stages of coccidia. Measurements of endogenous stages were made on 15 individuals of each life stage. Samples of oocysts preserved in $70 \%$ ethanol, histological sections of the small intestine infected with endogenous stages, and digital images of photomicrographs have been deposited in the Harold W. Manter Laboratory collection (HWML) and voucher frog specimens in the division of zoology, University of Nebraska State Museum (UNSM), Lincoln, Nebraska.

\section{RESULTS}

Of the 6 adult anuran species examined during March 2001 to May 2002, only 23 of 30 adult $P$. $t$. triseriata shed oocysts of Isospora n. sp., and 2 of 30 adult P. t. triseriata shed oocysts of E. streckeri during March to April 2002. Two adult frogs 
TABLE I. Prevalence of Coccidian parasites in 6 anuran species collected from Pawnee Lake, Lancaster County, Nebraska during March 2001 to June 2002.

\begin{tabular}{lcc}
\hline \multicolumn{1}{c}{$\begin{array}{c}\text { Anuran } \\
\text { species }\end{array}$} & $\begin{array}{c}\text { No. infected/ } \\
\text { no. examined } \\
\text { percentage }\end{array}$ & $95 \% \mathrm{CI}^{*}(\%)$ \\
\hline Rana blairi & $0 / 47(0)$ & 0 to 8 \\
R. blairi tadpoles & $0 / 16(0)$ & 0 to 21 \\
R. catesbeiana & $0 / 35(0)$ & 0 to 10 \\
Hyla chrysoscelis & $0 / 31(0)$ & 0 to 11 \\
Pseudacris triseriata triseriata & $23 / 30(77)$ & 58 to 89 \\
$P$. t. triseriata tadpoles $\dagger$ & $4 / 46(9)$ & 3 to 21 \\
Acris crepitans & $0 / 8(0)$ & 0 to 36 \\
Bufo woodhousii & $0 / 11(0)$ & 0 to 26 \\
5 genera/6 species & $27 / 224(12)$ & 8 to 17 \\
\hline
\end{tabular}

* CI, confidence interval.

$+0 / 30(0 \%, 95 \%$ CI 0 to $11 \%)$ tadpoles collected in April 2002 shed oocysts, 4 $16(25 \%, 95 \%$ CI 9 to $50 \%)$ tadpoles collected in May-June 2002 shed oocysts of Isospora cogginsi n. sp. were concurrently infected with both coccidian species. The 30 $P$. $t$. triseriata tadpoles collected during April 2002 (Gosner stages 26-30) were negative for coccidia. Additionally, none of the 16 field-collected $R$. blairi (Gosner stages 26-30) tadpoles that were maintained in the laboratory for a period of 2-6 wk shed coccidian oocysts, whereas $25 \%$ (4 of 16 ) of $P$. $t$. triseriata tadpoles (Gosner stages 27-37) shed oocysts of Isospora n. sp. in late June 2002 (Table I). Below are descriptions of 2 species of coccidia found in $P$. $t$. triseriata collected from Nebraska.

\section{DESCRIPTION}

\section{Eimeria streckeri Upton and McAllister, 1988}

(Figs. 1-5)

Oocysts spherical, rarely subspherical, $15.7 \times 15.4(14-17$ $\times 14-19)$, with a thin, smooth, single-layered, colorless wall ca. 0.6 thick; shape index 1.01 (1.0-1.1). Micropyle absent. Subspherical membrane-bound oocyst residuum present, $5 \times$ $4.7(3-6 \times 4-6)$, with numerous granules surrounding a large vacuolated area, and a globularlike body within the vacuole, $1.5(1.0-1.9)$ in diameter. Sporocysts ovoid, $9.1 \times 6.1(7-10 \times$ 5-7), with a thin, colorless, smooth wall ca. 0.4 thick; shape index 1.5 (1.3-1.7). One end of the sporocyst thickened to form a Stieda body. Sporocyst residuum present, $5.8 \times 3.6(3-8 \times$
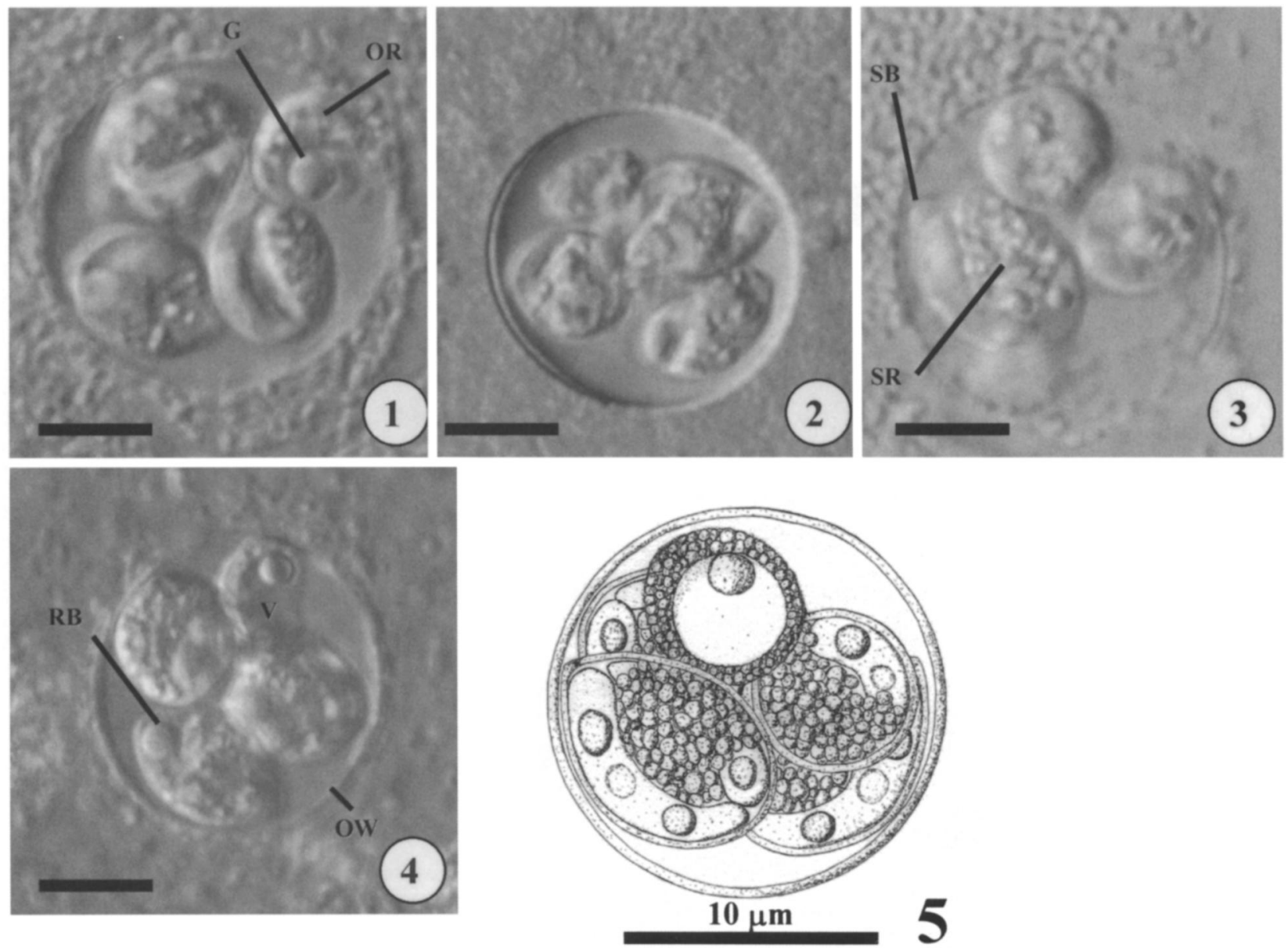

FIGURES 1-4. Nomarski interference contrast photomicrographs of oocysts of Eimeria streckeri (OR, oocyst residuum; OW, oocyst wall; RB, refractile body; G, globularlike body; SB, Stieda body; SR, sporocyst residuum; V, vacuolated area in oocyst residuum.). Bar $=5 \mu \mathrm{m}$.

FIGURE 5. Composite line drawing of an oocyst of Eimeria streckeri from Pseudacris triseriata triseriata. 
2-6), with numerous fine granules, many scattered among the sporozoites. Sporozoites elongate, $7.9 \times 2.2(6.5-10 \times 2-3)$, each with 2 refractile bodies. Spherical or ovoid anterior-central refractile body, $1.9 \times 1.9(1.8-2.2 \times 1.8-2.0)$; posterior refractile body spherical or ovoid, $2.5 \times 2.3(1.8-3.0 \times 2.0-2.8)$. Indistinct nucleus located between the refractile bodies.

\section{Taxonomic summary}

Type host: Pseudacris streckeri streckeri Wright and Wright, 1933, Streckers's chorus frog (Anura: Hylidae).

Other hosts: Pseudacris triseriata triseriata (Wied, 1839), western chorus frog (Anura: Hylidae).

Type locality: Dallas County, Texas.

Other localities: Pawnee Lake, Lancaster County, Nebraska $\left(40^{\circ} 51.18^{\prime} \mathrm{N}, 96^{\circ} 53.11^{\prime} \mathrm{W}\right)$.

Sporulation: Endogenous.

Site of infection: Unknown. Oocysts recovered from rectal contents and feces.

Prevalence: Sixteen of $34(47.1 \%)$ of adult P. s. streckeri from Dallas, Texas shed oocysts. In our study 2 of $30(7 \%)$ of adult $P$. $t$. triseriata shed oocysts.

Material deposited: Photos of sporulated oocysts, HWML 16977.

Host: Pseudacris triseriata triseriata, UNSM ZM-23844.

\section{Remarks}

Upton and McAllister (1988) and Duszynski et al. (2000) reviewed the Eimeria species of anurans. These investigators indicated that half of Eimeria species have spherical or subspherical oocysts, and of these, only 5 have been reported to possess an oocyst residuum: E. algonquini Chen and Desser, 1989; E. cyanophlyctis Chakravarty and Kar, 1944; E. leptodactyli Carini, 1931; E. prevoti (Laveran and Mesnil, 1902); and E. streckeri, Upton and McAllister, 1988. The oocysts from our study closely resemble E. streckeri described from $P$. streckeri from Texas. Our specimens from $P$. $t$. triseriata and E. streckeri from $P$. s. streckeri had the same shape indices (1.0-1.1), sporulated oocysts overlapped in their range (18-23 $\times 11-20$ vs. $16.8-21.5 \times 16.8-20.8)$, and both contained a unique membrane-bound oocyst residuum. They differed in having on average smaller oocysts $(15.7 \times 15.4$ vs. $18.8 \times$ $18.7)$, sporocysts $(9.1 \times 6.1$ vs. $11.1 \times 7.7)$, and oocyst residua $(5 \times 4.7$ vs. $8 \times 8)$. The only major discrepancy between the description of Upton and McAllister (1988) of E. streckeri in Texas and the specimens described here is the presence of a distinctive globularlike body in the oocyst residuum, which did not change during a period of 6 mo while being refrigerated in $2.5 \%$ potassium dichromate. Because of our lack of knowledge of host-induced variation in amphibian Eimeria species and the similarity between our oocysts and those described for $P$. $s$. streckeri, we are of the opinion that it is probably best not to differentiate these as distinct species until cross-transmission or molecular data, or both, are available.

\section{DESCRIPTION}

Isospora cogginsi n. sp.

(Figs. 6-10)

Oocysts ovoid, rarely subspherical, $19.3 \times 15.1(18-23 \times$ 11-20), with a thin, smooth, colorless, single-layered wall ca.
0.5 thick; shape index 1.28 (1.1-1.6), wall frequently rupturing after sporulation, releasing free sporocysts. Micropyle, polar granule, and oocyst residuum absent. Sporocysts ovoid, $13.3 \times$ $9.9(11-15 \times 9-13)$, with a thin, colorless, smooth wall ca. 0.4 thick; shape index 1.3 (1.0-1.6), Stieda body absent. Sporocyst residuum present, $5.5 \times 5.3(4-7 \times 4-7)$, consisting of granules bound by a membrane. Sporozoites elongate, $12.8 \times 3.2(10-$ $15 \times 2.5-4)$, arranged so that 2 sporozoites lie in 1 direction, and the other 2 lie in the opposite direction. Each sporozoite with 2 refractile bodies, spherical or ovoid; anterior-central refractile body, $2.3 \times 2.4(2-3 \times 1.8-3)$; posterior refractile body spherical or ovoid, $2.6 \times 2.4(2.0-3.0 \times 2.2-2.8)$. Indistinct nucleus located between the refractile bodies, $1.5 \times 1.7$ (1.4$1.6 \times 1.5-1.8)$.

\section{Taxonomic summary}

Type host: Pseudacris triseriata triseriata (Wied, 1839), western chorus frog (Anura: Hylidae).

Type locality: Pawnee Lake, Lancaster County, Nebraska $\left(40^{\circ} 51.18^{\prime} \mathrm{N}, 96^{\circ} 53.11^{\prime} \mathrm{W}\right)$.

Sporulation: Exogenous; oocysts passed unsporulated and semisporulated in the sporoblast stage, becoming fully sporulated within 12-24 $\mathrm{hr}$ at room temperature after being defecated by the host.

Site of infection: Small intestine.

Endogenous development (Figs. 11-17): Histological examination of frogs infected with $I$. cogginsi putatively identified as this coccidian revealed endogenous stages including developing microgamonts, mature microgamonts, mature macrogamonts, and young unsporulated oocysts (Figs. 11, 12) located in the cytoplasm of the luminal epithelial cells of the small intestine. All identified stages were located in the posterior segment of the small intestine, although in heavily infected frogs, endogenous stages were found throughout the small intestine. In the host cells, parasites were generally located toward the apical portions of the luminal epithelial cells above the nucleus; however, in some host cells, fully formed macro- and microgamonts occupied the basal aspect of the cell, displacing the nucleus laterally or apically. Additionally, the released oocysts were in the process of sporulation within the lumen of the small intestine. Endogenous stages had the following measurements: developing microgamonts (Fig. 12), $11.6 \times 9.3(10-16 \times 7-$ $12)$, contained peripherally located nuclei; mature microgamonts (Fig. 13), $18.2 \times 14.8(16-22 \times 13-17)$, contained numerous microgametes; mature macrogamonts (Fig. 14), $11.9 \times$ $10.3(14-10 \times 8-13)$, contained numerous granules and vacuoles. Oocysts released from epithelial cells (Figs. 15, 16), 14.1 $\times 11.7(12-15 \times 10-13)$, were more basophilic, contained granules and vacuoles, and began sporulating in the gut lumen. Additionally, histological examination of the 3 tadpoles (Gosner stages 31-37), which shed oocysts of I. cogginsi, revealed fully developed macrogametes, developing microgamonts, mature oocysts, and mature meronts, all located in the epithelial cells of the small intestine, as well as oocysts in the process of sporulating in the gut lumen. Mature meronts (Fig. 17), $14.8 \times 8.8$ $(12-19 \times 7-10)$, contained 8-9 banana-shaped merozoites, 6.1 $\times 1.4(5-7 \times 1-2)$.

Prevalence: Twenty-three of $30(77 \%)$ adult animals shed 

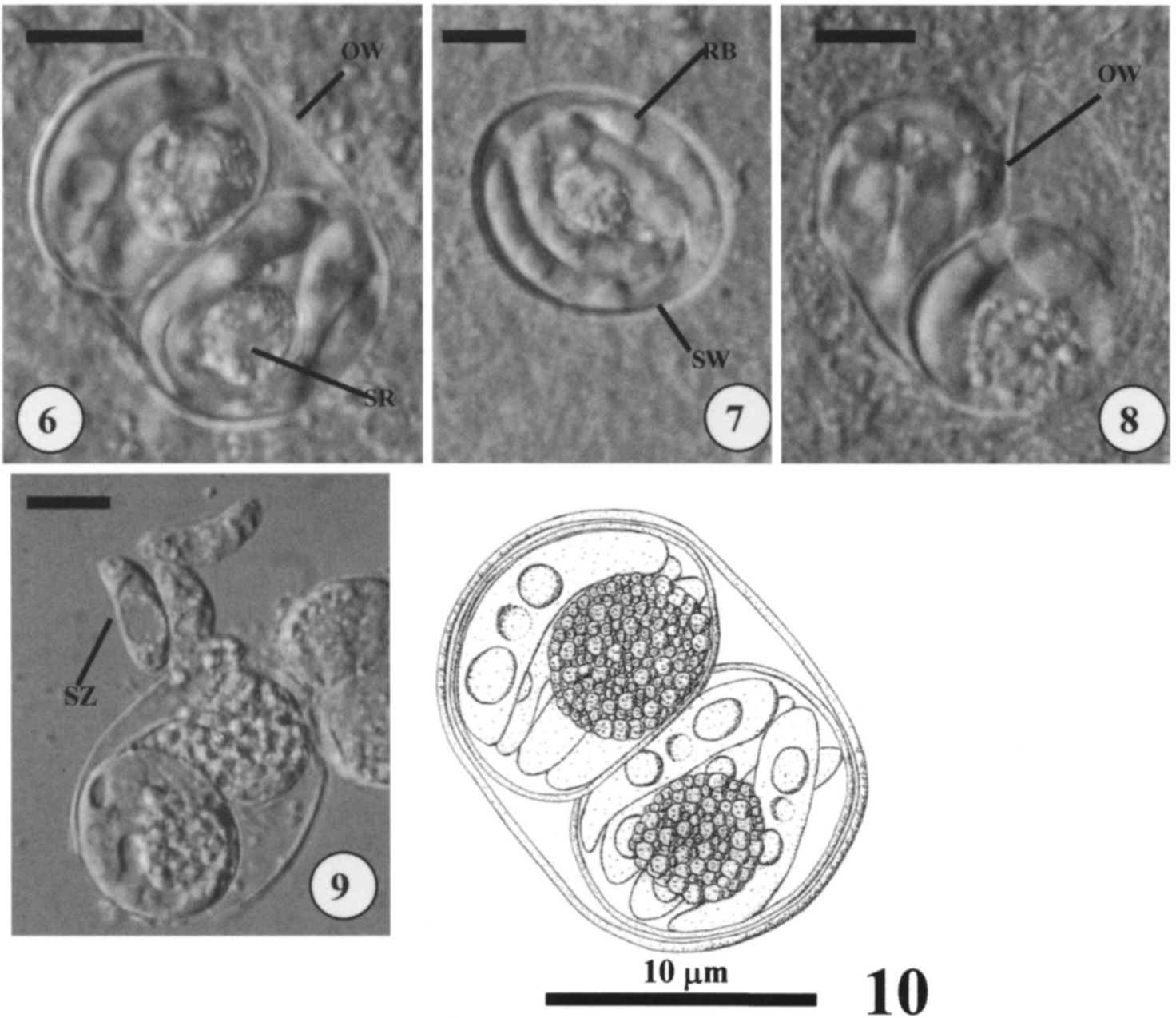

FIGURES 6-9. Nomarski interference contrast photomicrographs of oocysts, sporocysts, and sporozoites of Isospora cogginsi n. sp. 6. Oocyst of Isospora cogginsi $\mathrm{n}$. sp. (OW, oocyst wall; SR, sporocyst residuum). Bar $=6 \mu \mathrm{m}$. 7. Sporocyst of Isospora cogginsi $\mathrm{n}$. sp.; note the arrangement of the sporozoites: 2 lie in 1 direction, and the other 2 lie in the opposite direction (RB, refractile body; SW, sporocyst wall). Bar $=5 \mu m$. 8-9. Isospora cogginsi $\mathrm{n}$. sp. during collapse of oocyst wall (OW, oocyst wall; SZ, sporozoite). Bar $=8 \mu \mathrm{m}$.

FIGURE 10. Composite line drawing of an oocyst of Isospora cogginsi $\mathrm{n}$. $\mathrm{sp}$

oocysts during March-April, and 4 of 16 (25\%) laboratorymaintained tadpoles shed oocysts during June.

Material deposited: Sporulated oocysts preserved in $70 \%$ ethanol, HWML 16978. Photosyntypes of sporulated oocysts, HWML 16979. Histological sections of adult frog small intestine, HWML 16980. Histological section of tadpole small intestine, HWML 16981.

Type host: Pseudacris triseriata triseriata, UNSM ZM23844.

Etymology: The specific epithet is named in honor of James R. Coggins, who allowed the senior author the freedom to study amphibian parasites during his Masters thesis research.

\section{Remarks}

Upton and McAllister (1988) and Duszynski et al. (2000) reviewed the Isospora species of anurans. Of the 22 species of Isospora reported from anuran hosts, I. cogginsi most closely resembles I. cruzi Pinto and Vallim, 1926, from Scinax spp. (Hylidae) from South America (Pinto and Vallim, 1926; Carini, 1936; Walton, 1947). Isospora cogginsi differs from I. cruzi in being slightly smaller $(19.3 \times 15.1$ vs. $20.7 \times 17.2)$ and more ovoid in shape (1.28 vs. 1.20$)$. In addition, the sporocyst residuum is bound by a membrane. Unfortunately, very few data were given in the description of $I$. cruzi, and the species should be considered a species inquirenda. On the basis of differing hosts, geographical location, and slight morphological differences, we believe the North American form should be regarded as a new species.

\section{DISCUSSION}

In their comprehensive review of anuran coccidians, Upton and McAllister (1988) suggested strict host specificity. Of the 6 species of frogs we examined from Nebraska, only western chorus frogs were infected with coccidians. Importantly, at our study site all frog species were collected from the same general location and overlap in habitat use, particularly during the breeding season (Vogt, 1981; Collins, 1993). Both R. catesbeiana and $R$. blairi commonly feed on breeding $P$. $t$. triseriata at this location (M. Bolek, pers. obs.) and, therefore, have a high probability of ingesting sporulated oocysts of E. streckeri. 

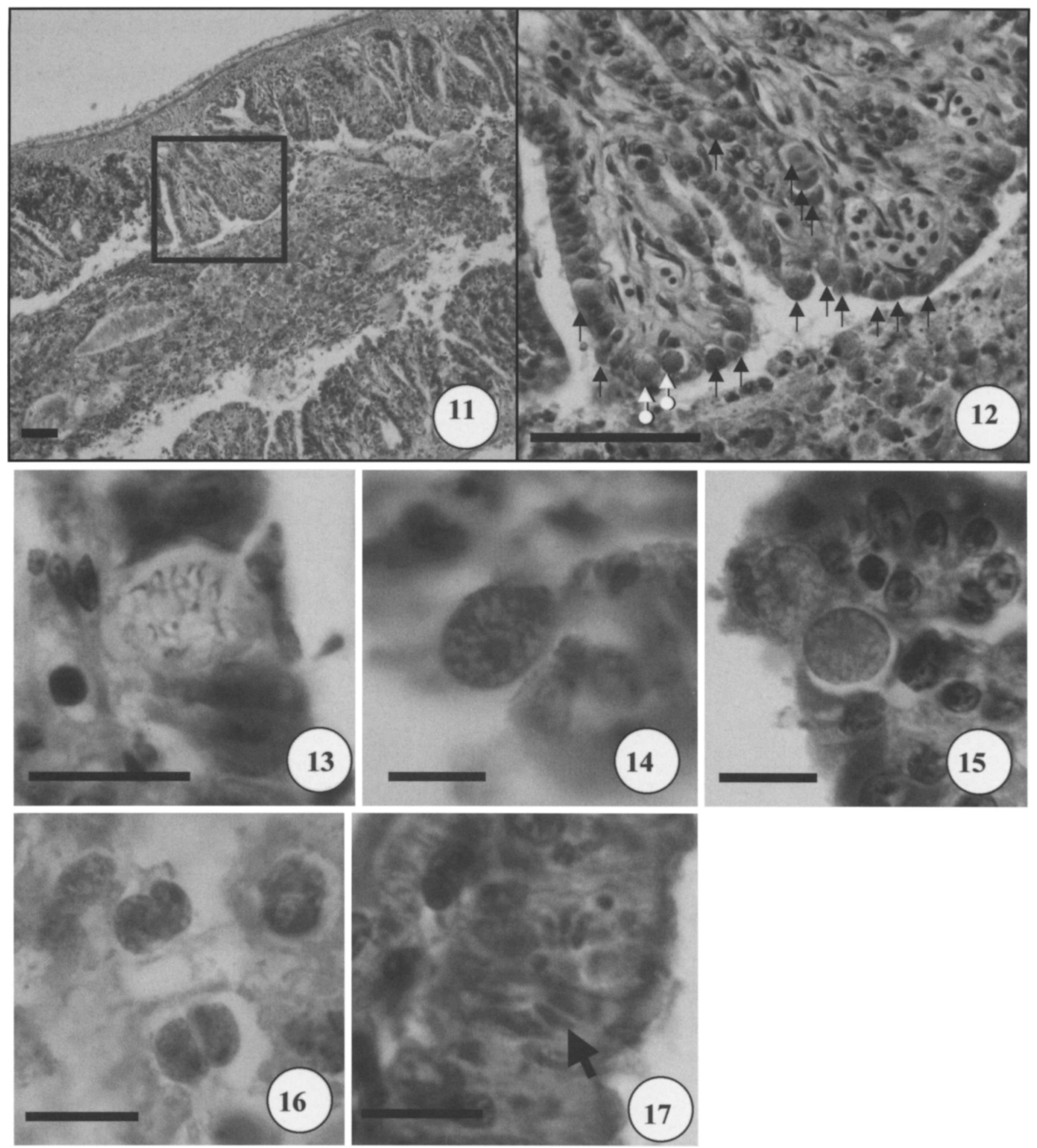

Figures 11-16. Photomicrographs of endogenous stages of Isospora cogginsi n. sp. in Bouin's fixed tissue from adult Pseudacris triseriata triseriata. 11. Longitudinal section of the small intestine of Pseudacris triseriata triseriata; note the large number of oocysts in the lumen of the gut. Hematoxylin and eosin. Bar $=90 \mu \mathrm{m}$. 12. Higher magnification of the area delineated by the square in Figure 11, demonstrating numerous developing macrogamonts (black arrow) and developing microgamonts (white arrow) within mucosal epithelial cells of intestinal villi. Hematoxylin and eosin. Bar $=90 \mu \mathrm{m}$. 13. Mature microgamont. Hematoxylin and eosin. Bar $=18 \mu \mathrm{m}$. 14. Mature macrogamont. Hematoxylin and eosin. Bar $=10 \mu \mathrm{m}$. 15. Young oocyst. Hematoxylin and eosin. Bar $=15 \mu \mathrm{m}$. 16. Lumen of the small intestine; oocysts in the initial stages of sporulation. Hematoxylin and eosin. Bar $=15 \mu \mathrm{m}$.

FIGURE 17. Mature meront with merozoites (black arrow) in an intestinal epithelial cell of a Pseudacris triseriata triseriata tadpole. Hematoxylin and eosin. Bar $=12 \mu \mathrm{m}$. 
These observations may be important when considering that most anuran coccidians are fully sporulated in the gut lumen of their amphibian hosts and, therefore, are probably directly infective when ingested (Paperna and Lainson, 1995). Our data support observations by Upton and McAllister (1988) that most anuran coccidia rarely cross species boundaries. A recent review by Duszynski et al. (2000) indicates that of the 22 species of Eimeria and 22 species of Isospora reported from anurans, I. cruzi has been shown to infect 4 species of Scinax (treefrogs, Hylidae), whereas 4 Eimeria species and 2 Isospora species have been shown to infect multiple species of true frogs (Ranidae), i.e., Rana. If our specimens of E. streckeri from Nebraska chorus frogs and the ones described by Upton and McAllister (1988) from Texas $P$. streckeri are really a single species, it can also be added to the list of coccidians that can infect multiple species of frogs. Therefore, it appears that at least some anuran coccidian species can infect multiple species of frogs in the same genus, but none is known to cross generic boundaries. Unfortunately, few studies examine amphibians of multiple species from the same location for coccidian parasites. More field studies and experimental infections must be conducted before we have a better understanding of host specificity of coccidian parasites of frogs.

In our study, tadpoles of frogs were not infected with $E$. streckeri, whereas $25 \%$ of laboratory-maintained $P$. $t$. triseriata tadpoles shed oocysts of $I$. cogginsi during June 2002. Relatively little information is available on field diets of tadpoles (Alford, 1999), but, in general, temperate-zone tadpoles such as Pseudacris spp. are indiscriminate feeders on suspended algae, supplementing their diets by grazing on attached or epibenthic algae (Whitaker, 1971; Seale and Beckvar, 1980; Seale, 1987). We usually observed benthic invertebrates such as Arcella ameba and benthic diatoms in the fecal pellets of field-collected and laboratory-maintained $P$. $t$. triseriata tadpoles. This suggests that these tadpoles may commonly come in contact with oocysts of I. cogginsi that were defecated into Pawnee Lake by adult frogs during the breeding season. Therefore, our observations imply that adult frogs may contaminate ponds with oocysts and infect tadpoles directly when they ingest sporulated oocysts. In a review of endoparasites of Cope's gray treefrogs and western chorus frogs, Bolek and Coggins (1998) indicated that breeding ponds may serve as important foci of infections for endoparasites of treefrogs. From the present observations, it appears that breeding ponds may also be important foci for infections of tadpoles of $P$. t. triseriata, certainly with $I$. cogginsi.

Unfortunately, tadpoles have been surveyed for coccidians even less frequently than adult anurans (Noller, 1920; Upton and McAllister, 1988; Molnar, 1995). Noller (1920) and Molnar (1995) reported E. neglecta in tadpoles of Rana spp., whereas Upton and McAllister (1988) did not find any coccidians in the 5 tadpoles of $P$. $s$. streckeri they examined. There is no other report of Eimeria or Isospora species from tadpoles of anurans. In his study on E. neglecta, Noller (1920) reported that adult frogs are never infected with $E$. neglecta and that tadpoles lose their infections during metamorphosis. Unfortunately, the periphery of Pawnee Lake, where we sampled our chorus frogs and tadpoles, dried, and we could not collect any additional tadpoles or metamorphosed chorus frogs from this location. We did sample an additional 19 metamorphosed chorus frogs from another adjacent pond in June that also dried, but none was shedding oocysts. Although our study is the first to demonstrate coccidian infections in adult and tadpole stages of the same species of frogs, it is unclear if anuran tadpoles can retain infections through metamorphosis. Interestingly, coccidians of caudate amphibians, which also have exogenous development, commonly infect adult, immature, and larval salamanders of the same species, and it is likely that $I$. cogginsi may also be retained by frogs through metamorphosis (Saxe, 1955; Duszynski et al., 1972; McAllister and Upton, 1987; Upton et al., 1993). In fact, we have maintained larval tiger salamanders, Ambystoma tigrinum mavortium, collected from western Nebraska in the laboratory, which continued to shed oocysts of $E$. ambystomae for up to $2 \mathrm{wk}$ after metamorphosis (data not shown). Because anuran and caudatan amphibian species commonly shed oocysts of coccidians during their breeding season (Saxe, 1955; McAllister and Upton, 1987; Upton and McAllister, 1988; Upton et al., 1993; Bolek, 2000; Modry et al., 2001), and in light of the fact that other intestinal protozoa of adult frogs commonly infect anurans in the tadpole stage, we hypothesize that adult amphibians may commonly contaminate breeding ponds with oocysts and may infect tadpoles and larvae of those species (Smyth and Smyth, 1980). It remains to be seen what role, if any, tadpoles play in the epizootiology and ecology of anuran coccidians. It would be particularly interesting to see if there are any differences in the role amphibian tadpoles may play in the transmission of coccidians with endogenous development, which are apparently directly infective to adult frogs, as opposed to species with exogenous development, which must go through a period of development in the external environment.

\section{ACKNOWLEDGMENTS}

We thank M. Ewert, School of Pharmacy and Pharmacal Sciences, Purdue University, for help in collecting frogs; J. Detwiler, School of Biological Sciences, University of Nebraska-Lincoln, for help in collecting tadpoles; K. R. Kazacos, Department of Veterinary Pathobiology, Purdue University, for introducing M.G.B. to coccidia; N. Martin, Department of Veterinary Pathobiology, Purdue University, for her histotechnical expertise and assistance; S. L. Gardner and A. Jimenez Ruiz, Harold W. Manter Laboratory, University of Nebraska-Lincoln, for help with Nomarski photomicroscopy; S. J. Upton, Division of Biology, Kansas State University, and D. W. Duszynski, Department of Biology, The University of New Mexico, for providing pertinent literature, discussion, and reviewing the manuscript; and B. Hanelt, School of Biological Sciences, Louisiana State University, for his translations of German papers on amphibian coccidians. This work was supported by grants from the Initiative for Ecological and Evolutionary Analysis, University of Nebraska-Lincoln; The Franklin Kestner Memorial Fund School of Biological Sciences, University of Nebraska-Lincoln; and the Center for Great Plains Studies graduate student grant-in-aid, University of Nebraska-Lincoln.

\section{LITERATURE CITED}

Alford, R. A. 1999. Ecology: Resource use, competition and predation. In Tadpoles: The biology of anuran larvae, R. W. McDiarmidm and R. Altig (eds.). The University of Chicago Press, Chicago, Illinois, p. 240-278.

BoleK, M. G. 2000. Tiger salamander. Coccidia. Herpetological Review 31: 97.

- AND J. R. CogGins. 1998. Endoparasites of Cope's gray treefrog, Hyla chrysoscelis, and western chorus frog, Pseudacris $t$. triseriata, from southeastern Wisconsin. Journal of the Helminthological Society of Washington 65: 212-218.

CARINI, A. 1936. Isospora cruzi, parasita dell 'ntestino di alcune ile del 
Brasile. Archivio Italiano Di Scienze Mediiche Coloniali ee Di Parassitologia 17: 610-613.

Chen, G. J., AND S. S. Desser. 1989. The coccidia (Apicomplexa: Eimeriidae) of frogs from Algonquin Park, with descriptions of two new species. Canadian Journal of Zoology 67: 1686-1689.

Collins, J. T. 1993. Amphibians and reptiles in Kansas, 3rd ed. Public Education Series 13. The University of Kansas Museum of Natural History, Lawrence, Kansas, 397 p.

Duszynski, D. W., L. Couch, AND S. J. Upton. 2000. Coccidia (Eimeria and Isospora) of Anura. Available at: http://biology.unm.edu/ biology/coccidia/anura.html.

, W. A. Riddle, D. R. Anderson, AND R. W. Mead. 1972. Coccidia from the tiger salamander, Ambystoma tigrinum, in northeastern Colorado and in northern New Mexico. Journal of Protozoology 19: 252-256.

GoldBerg, S. R., C. R. Bursey, AND C. Wong. 2002. Helminths of the western chorus frog from eastern Alberta, Canada. Northwest Science 76: 77-79.

GosNer, K. L. 1960. A simplified table for staging anuran embryos and larvae with notes on identification. Herpetologica 16: 225-232.

Laveran, M. A., AND F. Mesnil. 1902. Sur deux coccidies intestinales e la Rana esculenta. Comptes Rendus des Seances de la Société de Biologie et Ses Filiales 54: 857-860.

— AND — 1987. Endoparasites of the smallmouth salamander, Ambystoma texanum (Caudata: Ambystomatidae) from Dallas County, Texas. Journal of the Helminthological Society of Washington 54: 258-261.

McAllister, C. T., S. J. Upton, S. E. Trauth, and C. R. Bursey. 1995. Parasites of wood frogs, Rana sylvatica (Ranidae), from Arkansas, with a description of a new species of Eimeria (Apicomplexa: Eimeriidae). Journal of the Helminthological Society of Washington 62: $143-149$.

Modry, D., J. R. Slapeta, M. JiRku, M. Obornik, J. LuKes, and B KOUDELA. 2001. Phylogenetic position of a renal coccidium of the European green frogs, 'Isospora' lieberkuehni Labbe, 1894 (Apicomplexa: Sarcocystidae) and its taxonomic implications. International Journal of Systematic and Evolutionary Microbiology 51: 767-772.
MOLNAR, K. 1995. Redscription of Goussia neglecta n. comb. (Noller, 1920) (Apicomplexa: Coccidia) and notes on its occurrence in the gut of tadpoles. Acta Veternaria Hungarica 43: 265-275.

Noller, W. 1920. Zur Kenntnis der Coccidien des Wasserfrosches (Eimeria neglecta nov. spec.) Befruchtuing und sprogonie von Lankesterella. Archives Protistenkunde 41: 176-180.

PAPERNA, I., AND R. LAINSON. 1995. Life history and ultrastructure of Eimeria bufomarini n. sp. (Apicomplexa: Eimeriidae) of the giant toad, Bufo marinus (Amphibia: Anura) from Amazonian Brazil. Parasite 2: 141-148.

Pinto, C., AND A. R. VAluim 1926. Estudos sobre coccideas. Boletim Do Instituto Brasileiro De Sciencias 2: 216-219.

SAXE, L. H. 1955. Observations on Eimeria from Ambystoma tigrinum, with descriptions of four new species. Proceedings of the Iowa Academy of Sciences 62: 663-673.

Seale, D. B. 1987. Amphibia. In Animal energetics, vol. 2., T. J. Pandin and E. J. Vernberg (eds.). Academic Press, San Diego, California p. $467-552$.

, AND N. BECKVAR. 1980. The comparative ability of anuran larvae (genera: Hyla, Bufo and Rana) to ingest suspended bluegreen algae. Copeia 1980: 495-503.

SMYTH, J. D., AND M. M. SMYTH. 1980. Frogs as host-parasite systems. 1. Macmillan, London, U.K., $212 \mathrm{p}$

Upton, S. J., AND C. T. MCAllister. 1988. The coccidia (Apicomplexa: Eimeriidae) of Anura, with descriptions of four new species. Canadian Journal of Zoology 66: 1822-1830.

, AND S. E. TRAuTh. 1993. The coccidia (Apicomplexa: Eimeriidae) of Caudata (Amphibia), with descriptions of two new species from North America. Canadian Journal of Zoology 71: $2410-2418$.

VoGT, R. C. 1981. Natural history of amphibians and reptiles of Wisconsin. The Milwaukee Public Museum and Friends of the Museum, Milwaukee, Wisconsin, 205 p.

Walton, A. C. 1947. Parasites of the Hylidae (Amphibia-Hylinae). VI. Transactions of the Illinois State Academy of Sciences 40: 205214.

Whitaker, J. O. JR. 1971. A study of the western chorus frog, Pseudacris triseriata, in Vigo County Indiana. Journal of Herpetology 5: $127-150$. 